\title{
Microsatellite analysis to study genetic diversity in Khasi Pine (Pinus kesiya Royle ex. Gordon) us- ing chloroplast SSR markers
}

\author{
Kirti Chamling Rai*, H. S. Ginwal
}

Division of Genetics and Tree Propagation, Forest Research Institute, P.O.I.P.E. Kaulagarh Road, Dehradun-248195, Uttarakhand, India

* Author for correspondence: Kirti Chamling Rai. Email: kirtichamling@gmail.com.

\begin{abstract}
Pinus kesiya (Khasi pine) is the principal pine species in northeast India having high commercial value. Chloroplast microsatellites (cpSSR) were used to study the genetic diversity and population genetic structure of 10 populations of $P$. kesiya covering entire natural range of distribution in India. A total of 33 primer pairs (cpSSRs) of $P$. thunberghii and $P$. sylvestris were tested in P. kesiya for their transferability, out of which 18 chloroplast primers showed positive amplification and 10 were found polymorphic. A total of 250 individuals from 10 different populations were genotyped using the selected $10 \mathrm{cpSSRs}$. When alleles at each of the 10 loci were jointly analysed a total of 36 size variants were discovered, which combined to designate 90 haplotypes among 250 individuals. None of the haplotype was found common among the populations as they were population specific. The cpSSR indicated that $P$. kesiya populations have maintained a moderately high genetic diversity $\left(H_{\mathrm{T}}=0.638\right)$ which is typical in most coniferous species. However, the inter-population genetic diversity was higher than the intra population diversity and the genetic differentiation between populations was also found to be very high $\left(\mathrm{F}_{\mathrm{ST}}=0.47\right)$. A Bayesian cluster analysis separated the populations into six clusters where most of the individuals were found in single population clusters with minor admixtures. The distribution of genetic diversity and sub structuring of $P$. kesiya reflect week pollen mediated gene flow due to geographic isolation and genetic drift. The study has revealed useful cpSSR markers for $P$. kesiya, which were lacking earlier and also added an insight into the state of Khasi pine forest in the region, which can be useful for the better management and future conservation programs.
\end{abstract}

Keywords: : Simple sequence repeats, cPSSR, genetic diversity, Khasi Pine, P. kesiya.

\section{Introduction}

The genus Pinus is evolutionarily an ancient genus (Mirov, 1967; Miller, 1982) and is native to tropic as well as the temperate climate. They are widespread in South-East Asia and in India, they are found abundantly in the Himalayas with five species occurring naturally, viz., Pinus roxburghii Sargent, P. wallichiana Jackson, P. gerardiana Wall, P. kesiya Royle ex Gordon and $P$. merkusii Jungh and de Vriese. $P$. kesiya locally known as Khasi pine in India has a natural range of distribution in the Khasi and Jaintia hills in Meghalaya andoccurs in small patches in the states of Manipur, Nagaland and Arunachal Pradesh. It is the only sub-tropical pine that grows in the eastern Himalayas atelevations ranging from 800 to $2000 \mathrm{~m}$ (Chaudhary and Bhattacharyya, 2002). It is a major source of timber in the region and the locals exploit this species for resin extraction, firewood, etc. Also this fast-growing three-needle pine has high commercial value for its pulp and oleoresin and is subjected to overexploitation. Furthermore, fast paced urbanization in otherwise less populated habitats and unchecked developmental activities are having a negative impact on this species due to fragmentation of its habitats. Due to this, the pine forests are at a risk of losing their genetic base which is important for their sustenance and survival.

In recent years, special emphasis is given to forest conservation owing to the rapid loss of forest cover due to unrestrained urbanization and climate change. In order to conserve these fast diminishing natural forests, it is important to understand the extent of genetic diversity of the species under threat. Molecular marker techniques have helped immensely in assessing the genetic resources of plants (Porth and El-Kassaby, 2014) and levels of genetic diversity in tree species. It has helped to generate information and database which will be a step forward in pin pointing those populations which require special attention in terms of conservation and management. 
Microsatellite markers are frequently used for assessing the levels of genetic diversity as well as the genetic structuring at both population and species level in order to develop suitable conservation strategies (Frankham et al., 2002; LopezVinyallonga et al., 2011). They are becoming an extremely useful tool in population genetics due to their high variability and co-dominance (Provan et al., 1999). Moreover, high mutation rate of SSRs results in large standing allelic diversity (Ellegren 2004) and provides every individual with a unique genotype (Queller et al. 1993) using only a few loci (Ganea et al., 2015). Simple sequence repeats (SSRs) have been used extensively for characterizing the genetic diversity of Pine species all over the world. Recently, Cai et al. (2017), developed microsatellite markers for $P$. kesiya var. langbianensis, but still, very few microsatellite markers have been developed and reported in P. kesiya species. Since the cost and effort to procure SSRs is still significantly high, it is common practise to cross amplify primers designed from different sources in the target species (Moreno et al., 2011). Although P. kesiya is one of the principle species in the region having multiple uses, very little attention is given with regard to the conservation of its genetic resources mainly due to the unavailability of information regarding the genetic diversity of this species. The present work was undertaken not only to disclose the genetic diversity and population structure of $P$. kesiya in this region but also to identify cPSSR primer pairs for this species through trans-specific amplification from other species (i.e. P. sylvestris, Provan et al. 1998; and P. thunberghii, Vendramin et al. 1996).

Chloroplast microsatellite markers are highly variable having a relatively high rate of sequence evolution (Provan et al., 1999; Kelchner 2000; Diekmann et al., 2012).Bayer et al.(1999), reported that as chloroplast genomes show uniparental inheritance and do not recombine during sexual reproduction, different microsatellite loci are linked together and individual haplotypes can be easily detected by applying a set of different chloroplast microsatellite markers. The small genome size of cpDNA and the absence of sexual recombination make cpSSRs ideal markers for population and ecological genetics studies (Morgante et al., 1996).

In this paper, we have used chloroplast microsatellites to study 1) the levels of haplotypic diversity existing in populations and (2) the population genetic structure of the existing populations of $P$. kesiya along the whole distributional area in North East India. Ten cpSSR loci from 250 trees from 10 sites in the core distribution range of the species across Himalayan Mountains covering four states viz. Meghalaya, Arunachal Pradesh, Manipur and Nagaland were analysed. The information will be useful to guide gene conservation strategies for the species.

\section{Materials and Methods}

\section{Plant material}

Needles were collected from 10 geographically distinct populations from their natural range of distribution in Northeast
India, covering 4 states (Fig. 1). Twenty five adult individuals were randomly sampled in each population. Trees considered for collection were well spaced and separated from each other by at least $100 \mathrm{~m}$. This was done in order to avoid sampling individuals arising from the same maternal line. The samples were then stored at $-80^{\circ} \mathrm{C}$ prior to DNA isolation.

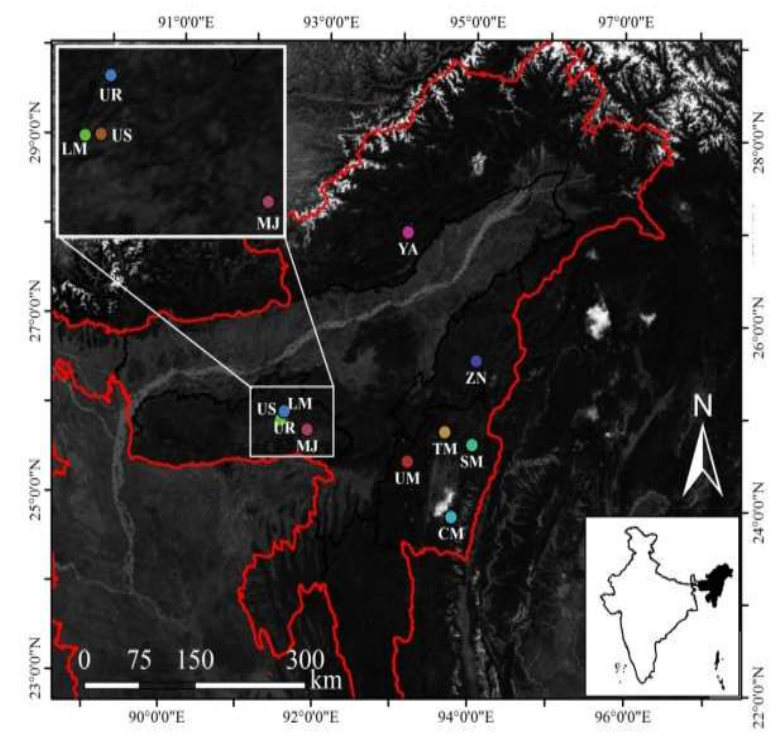

Figure 1

Map showing the geographical location of $P$. kesiya populations

\section{DNA extraction and PCR amplification}

Genomic DNA was extracted from needles of sampled trees using a modified CTAB method given by Doyle and Doyle (1990) and Stange et al. (1998). DNA quality was determined by gel electrophoresis using $0.8 \%$ agarose gel and the concentration was measured on a Biophotometer (Eppendorf-6131, Germany). The genomic DNA samples were diluted to a final concentration of $15 \mathrm{ng} / \mu \mathrm{L}$ for setting up the PCR reaction.

For trans-specific amplification, a total of 33 chloroplast SSR markers were used where $20 \mathrm{cpSSRs}$ were from $P$. thunberghii (Vendramin et al., 1996) and 13 were from $P$. sylvestris (Provan et al., 1998). These primers were tested for transference in P. kesiya. The protocol by Vendramin et al. (1996) with some modifications amplified the microsatellite loci in all populations of P. kesiya. Using gradient Polymerase chain reaction (PCR) the optimum annealing temperature was standardized. PCR amplifications were performed using $15-\mu \mathrm{L}$ reaction volumes containing 15 ng genomic DNA, 1x Taq buffer (Bangalore Genei Ltd.) , $3.0 \mathrm{mM}$ of $\mathrm{MgCl}_{2}$ (Bangalore Genei Ltd.), $0.2 \mathrm{mM}$ of dNTP (Bangalore Genei Ltd.), $0.2 \mu \mathrm{M}$ of forward and reverse primer (SIGMA-ALDRICH, USA) and 5 units of Taq Polymerase(Bangalore Genei Ltd.). Samples were amplified using Thermal cyclerwith thefollowing profile: initial denaturation $\left(94^{\circ} \mathrm{C}, 5 \mathrm{~min}\right)$, followed by 35 cycles of denaturation $\left(94^{\circ} \mathrm{C}, 1 \mathrm{~min}\right)$, annealing (locus-specific temperature, $1 \mathrm{~min})$, extension step $\left(72^{\circ} \mathrm{C}, 1\right.$ $\min )$ and a final extension $\left(72^{\circ} \mathrm{C}, 8 \mathrm{~min}\right)$. 
After PCR amplification, the amplicons were resolved on 8 $\%$ polyacrylamide gel (Wang et al., 2003)and theresolved bands were visualised under UV light trans-illuminator and the gel image was captured using a digital camera (Canon, EOS 400D). The details of the primers used for the study are given in Table 1.

\section{Scoring and analysis of data}

Scoring of each band was done manually and an input file was then prepared for statistical analysis.

\section{Haplotype distribution}

Since chloroplast has a haploid genome that is paternally inherited in pines (Neal and Sederoff, 1989; Watano et al., 1996) and does not undergo recombination, therefore it can be considered as a single locus. Each individual chloroplast haplotype was defined as the combination of the 10 polymorphic fragments obtained in P. kesiya. The following population genetic parameters were computed for each population: haplotype frequency $(p i)$, the effective number of haplotypes $(n e)=1 /\left(\sum \mathrm{pi}^{2}\right)$ and the unbiased haplotypic diversity $H_{\mathrm{e}}=[\mathrm{n} /(\mathrm{n}-1)]^{*}\left(1-\sum \mathrm{pi}^{2}\right)$ where $\mathrm{n}$ is the number of individuals analysed (Nei, 1987; Avise, 1994; Vendramin et al., 1998).

\section{Genetic diversity estimation}

The software POPGENE version 1.32 (Yeh et al., 1999) was used to calculate the total gene diversity $\left(H_{\mathrm{T}}\right)$ and diversity within population $\left(H_{\mathrm{s}}\right)$. The gene flow $(\mathrm{Nm})$ among populations was estimated by applying McDermott and McDonald's (1993) formula $\mathrm{Nm}=0.5\left(1-\mathrm{G}_{\mathrm{ST}}\right) / \mathrm{G}_{\mathrm{ST}}$ for the studied populations.

\section{Analysis of Molecular Variance (AMOVA)}

The analysis of molecular variance (AMOVA) was carried out in Arlequin software version 3.11 (Excoffier et al., 2005) to calculate the partitioning of genetic variation between and within the ten populations of $P$. kesiya.

\section{Structure analysis}

To estimate population structure among the individuals, we used a Bayesian analysis method using the software BAPS6 (Corander et al., 2013). Through this software individuals are clustered intogenetically distinguishable groups on the basis of allelefrequencies and linkage disequilibrium (Schug et al., 2007). Hidden population structure within populations is identified using this approach (Corander and Marttinen, 2006) as it first infers the most likely individual clusters in the sample population and then performs the most likely admixture of genotypes ( Corander et al., 2003).

For estimating the individual clustering we used $\mathrm{K}$ values ranging from 5-20 and the results obtained were used in an admixture analysis with 100 iterations to estimate the admixture coefficients for the individuals. The analysis was performed multiple times for each $\mathrm{K}$ value with 5-10 iterations and in each simulation were used 200 reference individuals and 100 iterations to estimate the admixture coefficients of the reference individuals.

\section{Results}

In the present study, the cpSSR primers used were derived from microsatellites developed from $P$. thunberghii and $P$. sylvestris. Thirty-three cPSSR primers were used to PCR-amplify ten populations of $P$. kesiya out of which only 18 amplified consistently under standard conditions. Ten of the $18 \mathrm{cpSSR}$ loci analysed (Pt15169, Pt107517, Pt45002, Pt51873, Pt63718, Pt100783, PCP9434, PCP36567, PCP45071, PCP71987) were polymorphic in all the $P$. kesiya populations investigated. The detail of these 10 primers has been presented in Table 1 .

Table 1

The detail of chloroplast microsatellite primers that were used for the study.

\begin{tabular}{|c|c|c|c|c|c|c|c|}
\hline S. No. & Primer & & Sequences (5'-3') & $\mathrm{Tm}\left({ }^{\circ} \mathrm{C}\right)$ & Product size (bp) & \begin{tabular}{l|l} 
Repeat motif \\
\end{tabular} & Reference \\
\hline \multirow{3}{*}{1} & \multirow{3}{*}{ Pt15169 } & Forward & \begin{tabular}{|l} 
CTTGGATGGAATAGCAGCC \\
\end{tabular} & \multirow{3}{*}{58.3} & \multirow{3}{*}{ 115-118 } & \multirow{3}{*}{$\left(C_{B}\left(T T_{B}(A T)_{B}\right.\right.$} & \multirow{3}{*}{ Vendramin et al., 1996} \\
\hline & & & & & & & \\
\hline & & Reverse & GGAAGGGCATTAAGGTCATTA & & & & \\
\hline \multirow{3}{*}{2} & \multirow{3}{*}{ Pt107517 } & Forward & AAAGCTTTITATGCGGCC & \multirow{3}{*}{54.6} & \multirow{3}{*}{95} & \multirow{3}{*}{$\left(T_{11}\right.$} & \multirow{3}{*}{ Vendramin et al., 1996} \\
\hline & & & & & & & \\
\hline & & Reverse & ATGGCAGTTCCAAAAAAGC & & & & \\
\hline \multirow{3}{*}{3} & \multirow{3}{*}{ Pt45002 } & Forward & AAGTTGGATTTACCCAGGTG & \multirow{3}{*}{56.2} & \multirow{3}{*}{ 161-167 } & \multirow{3}{*}{$(\mathrm{T}) / 5$} & \multirow{3}{*}{ Vendramin et al., 1996} \\
\hline & & & & & & & \\
\hline & & Reverse & GAACAAGAGGATTTTTCTCATACA & & & & \\
\hline \multirow{3}{*}{4} & \multirow{3}{*}{ Pt51873 } & Forward & AATCTTCTACGGAACGGAAA & \multirow{3}{*}{58.2} & \multirow{3}{*}{86} & \multirow{3}{*}{$(T)_{10}$} & \multirow{3}{*}{ Vendramin et al., 1996} \\
\hline & & & & & & & \\
\hline & & Reverse & ACAATITGGCTAGCAATGA & & & & \\
\hline \multirow{3}{*}{5} & \multirow{3}{*}{ Pt63718 } & Forward & CACAAAAGGATTाTाTाTAGTG & \multirow{3}{*}{52.9} & \multirow{3}{*}{$92-93$} & \multirow{3}{*}{$(T)_{10}$} & \multirow{3}{*}{ Vendramin et al., 1996} \\
\hline & & & & & & & \\
\hline & & Reverse & CGACGTGAGTAAGAATGGTTG & & & & \\
\hline & & Forward & ATACGTATGTATCCCCTAACTGTCA & & & & \\
\hline & & Reverse & TCAATTTTGGCATATCCTGA & & & 年/10 & 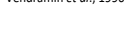 \\
\hline & & Forward & AAACTGACGTAGATGCCATGG & & & & \\
\hline 7 & PCP9434 & & & 58.5 & 131 & $(\mathrm{~A})_{10}$ & Provan et al., 1998 \\
\hline & & Reverse & GCGGTATGAGGGAAGAAGC & & & & \\
\hline & & Forward & AAAAGAGGAGGAAAAACACCTT & & & & \\
\hline 8 & РСР36567 & & & 58.5 & 115 & $\left(T_{/ 11}\right.$ & Provan et al., 1998 \\
\hline & & Reverse & AAGAGCAGACAGGTAAGGGGC & & & & \\
\hline & & Forward & ACTGGTCTGATCGACCCAAT & & & & \\
\hline 9 & PCP45071 & & & 58.5 & 149 & $(\mathrm{~T}) / 5$ & Provan et al., 1998 \\
\hline & & Reverse & TICTACACTTGCGGAAACCC & & & & \\
\hline & & Forward & TCTTGGAAGAAGGATGGCT & & & & \\
\hline & & Reverse & GGGGAGTAATCCGTGGAATT & 30.4 & 10 & (1/16 & 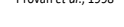 \\
\hline & & & & & & & \\
\hline
\end{tabular}

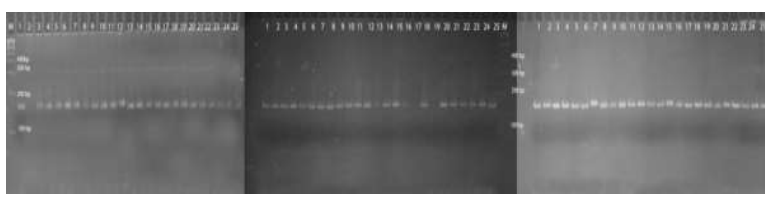

Lane M: 100 bp DNA ladder

Figure 2

Gel image showing alleleic variation at locus Pt100783 between the individuals of the populations of $P$. kesiya

\section{Haplotype distribution}

A total of 36 size variants were detected among the 250 individuals analysed.The variants were combined to designate 90 haplotypes and none of the haplotype was found common 
among the populations. Therefore, they were considered as population specific haplotypes. Table 2 shows the genetic characteristics of chloroplast haplotypes based on ten CPSSR loci in ten $P$. kesiya populations analysed. The highest value of haplotypic diversity was observed in $\mathrm{MJ}\left(H_{\mathrm{e}}=0.869\right)$ and the lowest in $\mathrm{CM}\left(H_{\mathrm{e}}=0.260\right)$. Estimates of the effective number of haplotypes $\left(n_{\mathrm{e}}\right)$ and haplotypic diversity $\left(H_{\mathrm{e}}\right)$ averaged across all the populations were 3.369 and 0.654 , respectively.

Table 2

Haplotypic distribution of ten populations of P. kesiya

\begin{tabular}{|c|c|c|c|c|c|c|}
\hline $\begin{array}{l}\text { Populations } \\
\end{array}$ & Location & $\mathrm{N}$ & Latitude/Longitude & Alt. (m) & ne & $\mathrm{He}$ \\
\hline us & Upper Shillong, Meghalaya & 25 & $25^{\circ} 35^{2} 2.5^{\prime \prime} \mathrm{N} / 91^{\circ} 54^{4} 0.95^{\prime \prime} \mathrm{E}$ & 1725 & 3.521 & 0.746 \\
\hline LM & Lumparing, Meghalaya & 25 & $25^{\circ} 33^{5} 3.6^{\prime \prime} \mathrm{N} / 9^{\circ} 1^{\circ} 2^{\prime} 10.7^{\prime \prime} \mathrm{E}$ & 1380 & 4.412 & 0.806 \\
\hline UR & Umiam, Ri-Bhoi, Meghalaya & 25 & $25^{\circ} 40^{\prime} 36.4^{\prime \prime \prime} \mathrm{N} / 9^{1} 55^{\prime} 53^{\prime} 7.2^{\prime \prime} \mathrm{E}$ & 874 & 4.261 & 0.797 \\
\hline MJ & Mookyndur, Jaintia Hills, Meghalaya & 25 & $25^{\circ} 7^{\prime} 3.22^{4} \mathrm{~N} / / 2^{\circ} 12^{\prime} 132.0^{\prime \prime} \mathrm{E}$ & 1350 & 6.050 & 0.869 \\
\hline YA & Yachuli, Arunachal Pradesh & 25 & $27^{\circ} 30^{\circ} 54.7^{\prime \prime \prime} \mathrm{N} / 93^{\circ} 47^{\circ} 0.65^{\prime \prime} \mathrm{E}$ & 493 & 4.900 & 0.829 \\
\hline $\mathrm{ZN}$ & Zunheboto, Nagaland & 25 & $26^{\circ} 0^{\circ} 33.41^{11^{\mathrm{N}} \mathrm{N} / 4^{4} 31^{\prime 2} 25.5^{\prime \prime} \mathrm{E}}$ & 1788 & 4.545 & 0.813 \\
\hline SM & Senapati, Manipur & 25 & 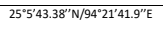 & 1600 & 1.563 & 0.375 \\
\hline TM & Tamenglong, Manipur & 25 & $25^{\circ} 16^{\prime} 3.82^{\prime \prime N} \mathrm{~N} / 94^{\circ} 1^{1} 15.66^{\prime \prime} \mathrm{E}$ & 1290 & 2.000 & 0.521 \\
\hline UM & Ukhrul, Manipur & 25 & $24^{\circ} 59^{\prime} 16.5^{\prime \prime} \mathrm{N} / 3^{\circ} 29^{\prime} 43.0^{\prime \prime} \mathrm{E}$ & 1200 & 2.000 & 0.521 \\
\hline CM & Chandel, Manipur & 25 & $25^{\circ} 19^{\prime} 34.3^{\prime \prime} \mathrm{N} / 94^{\circ} \mathrm{O}^{\prime} 2.16^{\prime \prime} \mathrm{E}$ & 790 & 1.333 & 0.260 \\
\hline Mean & & & & & 3.369 & 0.654 \\
\hline
\end{tabular}

\section{Genetic diversity estimation}

The effective number of alleles $\left(n_{\mathrm{e}}\right)$ ranged from 1.668 for Pt51873to 4.485 for Pt15169.The gene diversity $\left(H_{T}\right)$ levels for ten polymorphic loci ranged from 0.472 for Pt51873 to 0.768 for Pt15169. The within-population diversity $\left(H_{\mathrm{s}}\right)$ ranged from 0.149 for PCP36567to 0.367 for PCP45071 with a mean of 0.251 . The gene flow $\left(N_{\mathrm{m}}\right)$ was equal to 0.324 which shows that gene flow was low for this species (Table 3 ).

\section{AMOVA analysis}

Analysis of Molecular variance (AMOVA) was carried out to calculate the partitioning of genetic variation between and within the ten populations of $P$. kesiya using software Arlequin version 3.11 (Excoffier et al., 2005). The analysis revealed a more or less equal proportion of total variation distributed within and among populations ( $52.81 \%$ of the total variation within populations and $47.19 \%$ among populations). However, the populations revealed relatively high genetic differentiation $\left(F_{S T}=0.47\right)$ and inter-population diversity. $\underline{\text { Table } 3}$

Genetic diversity indicators for the ten chloroplast SSR markers

\begin{tabular}{|c|c|c|c|c|c|}
\hline Locus & $n_{a}$ & $n_{e}$ & $H_{\mathrm{T}}$ & $H_{s}$ & $N_{\mathrm{m}}$ \\
\hline Pt15169 & 6.000 & 4.485 & 0.768 & 0.316 & 0.350 \\
\hline Pt107517 & 5.000 & 2.316 & 0.519 & 0.249 & 0.460 \\
\hline Pt45002 & 4.000 & 2.231 & 0.617 & 0.193 & 0.228 \\
\hline Pt51873 & 5.000 & 1.668 & 0.472 & 0.176 & 0.291 \\
\hline $\begin{array}{l}\text { Pt63718 } \\
\end{array}$ & 4.000 & 2.828 & 0.658 & 0.235 & 0.277 \\
\hline Pt100783 & 4.000 & 2.142 & 0.566 & 0.365 & 0.910 \\
\hline PCP9434 & 7.000 & 5.122 & 0.808 & 0.237 & 0.208 \\
\hline РСР36567 & 4.000 & 3.101 & 0.696 & 0.149 & 0.136 \\
\hline PCP45071 & 4.000 & 2.252 & 0.588 & 0.367 & 0.829 \\
\hline PCP71987 & 6.000 & 3.106 & 0.692 & 0.227 & 0.244 \\
\hline Mean & 4.900 & 2.925 & 0.638 & 0.251 & 0.324 \\
\hline
\end{tabular}

Table 4

Analysis of molecular variance (AMOVA) of P. kesiya for Chloroplast SSR markers

\begin{tabular}{|c|c|c|c|c|c|}
\hline Source of Variation & Df & $\begin{array}{l}\text { Sum of } \\
\text { squares }\end{array}$ & $\begin{array}{c}\text { Variance } \\
\text { components }\end{array}$ & $\begin{array}{c}\text { Percentage of } \\
\text { variation }\end{array}$ & $\begin{array}{c}\text { F- } \\
\text { statistics }\end{array}$ \\
\hline Among Populations & 9 & 415.16 & $1.76 \mathrm{Va}$ & 47.19 & $F_{S T}=0.47$ \\
\hline Within Populations & 240 & 474.40 & $1.97 \mathrm{Vb}$ & 52.81 & \\
\hline Total & 249 & 889.56 & 3.74 & & \\
\hline
\end{tabular}

\section{Population Structure analysis}

The Bayesian analysis methodology takes the number of populations as well as the allele frequencies in each population as random variables thereby detecting the hidden population substructure by clustering sampled populations into a panmictic group (Corander et al., 2004; Eliades et al., 2011). The BAPS analysis revealed that the highest posterior probabilities for the individual level analysis stabilized at $K=6$. The software divided the ten populations into 6 independent clusters for both the individual and admixture models. These groups to some extent correspond with the natural geographical distribution of $P$. kesiya. The result is shown in Figure 3. At $\mathrm{K}=6$, most of the populations are clustered independently with low levels of admixture in all the 250 individuals. Populations from Meghalaya (US - MJ) were divided into three groups, where US and UM were included in a common group (Pink). The population from Arunachal Pradesh (YA) was clustered separately while populations from Manipur showed admixtures. In case of population from ZN (Red), it displays a genotype (Pink) which 
is shared with individuals from US and UR. Similarly TM and UM also show genotypes common in US and UR with admixtures. SM has one independent genotype (Green), a second genotype (Pink) and a third (Red) common to ZN. The population from CM has one independent genotype (Yellow), which it shares with LM a second genotype found in US, UR and UM.

$K=6$

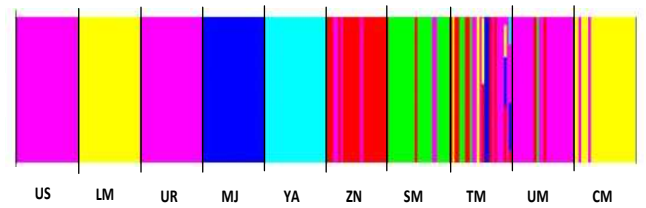

Figure 3-

Inferred clusters of individual genotypes with highest posterior probabilities of likelihood values obtained at $\mathrm{K}=6$. The colours represent the most likely ancestry of the cluster from which the genotype or partial genotype was drawn. The populations are separated by black vertical lines.

\section{Discussion}

Genetic diversity and gene flow

Genetic diversity is the basis of the evolutionary potential of species to respond to environmental changes and therefore becomes an essential pillar in conservation genetics (Toro and Caballero, 2005). The development of SSR markers is still inefficient, laborious and costly, principally in organisms with large and complex genomes, such as conifers. A number of researches have highlighted the ability of cross amplification in Pinus species (Villalobos-Arámbula et al., 2014; Xu et al., 2013; Chauhan et al., 2010; Xiang- Xiang and Ji-sen, 2005; Echt et al, 1998). In the present study, the population genetic parameters for ten populations of $P$. kesiya were estimated through transspecific amplification of chloroplast microsatellite markers from P. thunberghii (Vendramin et al. 1996) and P. sylvestris (Provan et al. 1998). The study demonstrated that the CPSSR primer pairs of other pine species can be successfully transferred in $P$. kesiya and can be utilized for population genetic analysis in this species. To date, no nuclear SSR markers have been developed for the P. kesiya species.

The cpSSRs showed a relatively high transfer rate in $P$. kesiya (subgenus Pinus) from $P$. thunberghii with $60 \%$ transfer rate followed by P. sylvestris with $46 \%$ transfer rate. A study by Cato and Richardson (1996) reported the successful transfer of chloroplast sequences from $P$. thunberghii to ten pine species. Chauhan et al. (2010) also successfully transferred $95 \%$ microsatellites from $P$. thunberghii, $100 \%$ from $P$. sylvestris, 20 to 28.57 \% from $P$. taeda, $33.33 \%$ from $P$. resinosa, 80 \% from P. merkusii and $42.85 \%$ from $P$. densiflora in $P$. roxburghii. Out of the primers which successfully transfer in $P$. kesiya ten loci were polymorphic.
The products amplified with the ten polymorphic primer pairs were in the expected size range (Table 1). A total of 36 size variants were found and these combined into 90 haplotypes with their frequencies ranging from 0.1 to 0.8 . None of the haplotype was found common or being shared among the populations. Therefore, they were considered as population specific haplotypes (Vendramin et al., 1998, 2000). The results indicate that $P$. kesiya in the region has maintained a high level of haplotypic diversity (mean $H_{e}=0.654$ ), which has been observed in most coniferous species based on cpSSRs (Tereb et al., 2006; Vendramin et al., 1998; Ribeiro et al., 2001; Gómez et al., 2003; Hansen et al., 2005; Clark et al., 2000). The haplotypic diversity was highest in population from Jowai, Meghalaya $\left(H_{\mathrm{e}}=0.869\right)$ indicating that this population should be considered for genetic conservation programs (Echt et al., 1998).

Overall total gene diversity at the ten chloroplast loci was high (mean $H_{T}=0.638$ ) which is in confirmatory to those reported by other authors (Gómez- Garay et al., 2010; Echt et al., 1998). However, the inter-population genetic diversity $\left(H_{T}-H_{S}\right)$ was higher than the diversity within populations (mean $\left.H_{\mathrm{s}}=0.251\right)$. This is also being supported by the high population genetic differentiation $\left(F_{\mathrm{ST}}=0.47\right)$. The gene flow estimate (mean $N_{\mathrm{m}}=0.324$ ) was relatively low for pines which is generally between the range of 4.6 and 17.2 (Ledig et al., 2001). However, the value is similar to the one found in P. roxburghii with average $N_{\mathrm{m}}=0.581$ (Chauhan, 2011). This indicates that there is little genetic exchange among the populations of $P$. kesiya resulting in high differentiation among populations. This may be due to the spatial distance of the geographical localities from where the populations were collected and lesser to do with the fragmentation of the pine forest resulting from anthropogenic activities although this possibility cannot be completely ruled out. Inbreeding and the presence of a subpopulation structure, where gene flow is prevented by habitat fragmentation, both cause the loss in heterozygosity (Hartl and Clark, 2007). This, in turn, results in increased genetic diversity among populations. Geographically widespread species generally show a significantly higher intra-population genetic diversity estimate compared to locally confined species, but the latter showed higher genetic diversity among populations (Hamrick 1992).

\section{Genetic differentiation}

Wright (1951) suggested that the $F_{\text {ST }}$ values above 0.25 indicate very high genetic differentiation (Hartl and Clark, 1997). Therefore, results for the cpSSRs in this study showed that the genetic differentiation was pronounced with $F_{S T}$ value of 0.47 indicating highly differentiated populations. The values are higher than those reported in most conifers such as Scottish P. sylvestris with $F_{S T}$ value of 0.37 (Sinclair et al., 1997), P. rzedowskii with $F_{\mathrm{ST}}$ value of 0.175 (Delgado et al., 1999) and P. pinceana with a value of 0.247 based on isozyme (Ledig et al., 2001). The low gene flow values due to geographical isolation resulting in higher chance of inbreeding within isolated populations may explain why the results of the present study revealed a high population differentiation. Moreover, restricted gene flow among 
populations (high $F_{\mathrm{ST}}$ ) may limit migration of genes or genotypes to new suitable habitats and may lead to local extirpation of populations and reduced genetic diversity in P.kesiya through the loss of rare alleles as they are affected by changing climate and anthropogenic pressure.

The Bayesian analysis identified 6 independent ancestries and some of them appeared within populations as well. Furthermore, the clusters showed very limited and in some populations no admixture indicating that they were highly differentiated probably due to weak pollen-mediated gene flow between populations. This may be due to the geographical boundaries that may act as barriers to gene flow and also as a result of the sporadic distribution of the populations under investigation. According to Perry (1991), genetic differentiation among populations is related to the species distribution on rugged mountain ranges where topography could act as a natural barrier to gene flow. Due to over exploitation of $P$. kesi$y a$ forests during the last several decades, it is presently restricted only in isolated patches of the Khasi and Jaintia hills in Shillong and in Manipur. The restricted gene flow may have prevented the exchange of alleles among $P$. kesiya populations resulting in the high genetic differentiation. Since the populations collected were geographically far apart it is possible that the populations have not admixed in recent history which is evident from the data that shows distinct clusters both within and among populations.

Genetic diversity provides the foundation for adaptation to changing environments (Aitken et al., 2008). Protection of genetic diversity both within and among populations is essential for species with more disjunct populations (Falk et al., 2006). To capture and maintain the genetic diversity for ex situ conservation of $P$. kesiya, we recommend making collections from as many populations as practical across the range, due to the moderate population structure and existence of uncommon population specific unique haplotypes. High genetic diversity areas such as Meghalaya region should be given special attention with regard to genetic conservation programs for the sustainable management of Khasi Pine forest. An integrated management plan including in-situ and ex-situ conservation strategies based on genetic, ecological and demographic data could maximize the maintenance of the existing genetic diversity in the long run and adaptation of $P$. kesiya to new threats and environmental changes.

\section{References}

AITKEN SN, YEAMAN S, HOLLIDAY JA, WANG T, CURTIS MCLANE S (2008) Adaptation, migration or extirpation: climate change outcomes for tree populations. Evolutionary Applications, 1(1): 95-111. https://doi.org/10.1111/j.1752-4571.2007.00013.x

AVISE JC (1994) Molecular Markers, Natural History and Evolution. Chapman and Hall, New York. https://doi.org/10.1007/978-1-4615-2381-9

BAYER C, FAY MF, DE BRUIJN AY, SAVOLAINEN V, MORTON CM, KUBITZKI K, ALVERSON WS, CHASE MW (1999) Support for an expanded family concept of Malvaceae within recircumscribed order Malvales: a combined analysis of plastid atpB and rbcL DNA sequences. Botanical Journal of the Linnean Society, 129: 267-303. https://doi.org/10.1111/j.1095-8339.1999.tb00505.x
CAI N, XU Y, WANG D, CHEN S, LI G (2017) Identification and characterization of microsatellite markers in Pinus kesiya var. langbianensis (Pinaceae). Applications in Plant Sciences, 5(2): 1-4. https://doi.org/10.3732/apps.1600126

CATO SA, RICHARDSON TE (1996) Inter- and intraspecific polymorphism at chloroplast SSR loci and the inheritance of plastids in Pinus radiata D. Don. Theoretical and Applied Genetics, 93: 587-592. https://doi.org/10.1007/s001220050319

CHAUDHARY V, BHATTACHARYYA A (2002) Suitability of Pinus kesiya in Shillong, Meghalaya for tree-ring analysis, Current Science, 83(8): 1010-1015.

CHAUHAN P (2011) Molecular genetic analysis of Chir pine (Pinus roxburghiiSargh.) through microsatellite markers. Ph.D. Thesis submitted to Forest Research Institute (Deemed) University.

CHAUHAN P, GINWAL HS, RAWAT A, BARTHWAL S (2010) Cross-species amplification and characterization of chloroplast and nuclear microsatellite markers in Himalayan Chir Pine (Pinus roxburghii Sarg).Molecular Ecology Resources, 11: 219-222.

CLARK CM, WENTWORTH TR, O'MALLEY DM(2000) Genetic discontinuity revealed by chloroplastmicrosatellites in Eastern North AmericanAbies (Pinaceae). American Journal of Botany,87: 774-782. https://doi.org/10.2307/2656885

CORANDER J, MARTTINEN P (2006) Bayesian identification of admixture events using multilocus molecular markers. Molecular Ecology, 15: 2833-2843. https://doi.org/10.1111/j.1365-294x.2006.02994.x

CORANDER J, WALDMANN P, SILLANPAA MJ (2003) Bayesian analysis of genetic differentiation between populations. Genetics, 163: 367-374.

CORANDER J, WALDMANN P, MARTTINEN P, SILLANPAA MJ (2004) BAPS 2: enhanced possibilities for the analysis of genetic population structure. Bioinformatics,20: 2363-2369. https://doi.org/10.1093/bioinformatics/bth250

CORANDER J, CHENG L, MARTTINEN P, SIREN J, TANG J (2013) BAPS: Bayesian analysis of population structure manual v. 6.0. http://www.helsinki.fi/bsg/software/BAPS/ Assessed 9 August 2018.

DELGADO P, PINERO D, CHAOS A, PEREZ-NASSER N, ALVAREZ-BUYLLA ER (1999) High population differentiation and genetic variation in the endangered Mexican pine Pinus rzedowskii (Pinaceae). American Journal of Botany, 86(5): 669-676. https://doi.org/10.2307/2656576

DIEKMANN K, HODKINSON TR, BARTH S (2012) New chloroplast microsatellite markers suitable for assessing genetic diversity of Lolium perenne and other related grass species. Annals of Botany, 110: 1327-1339.

https://doi.org/10.1093/aob/mcs044

DOYLE JJ, DOYLE JL (1990) A rapid total DNA preparation procedure for fresh plant tissue. Focus, 12: 13-15.

ECHT CS, DEVERNO LL, ANZIDEI M, VENDRAMIN GG (1998) Chloroplast microsatellite reveals population genetic diversity in red pine, Pinus resinosa Ait. Molecular Ecology, 7: 307-316. https://doi.org/10.1046/j.1365-294x.1998.00350.x

ELIADES N-GH, GAILING O, LEINEMANN L, FADY B, FINKELDEY R (2011) High genetic diversity and significant population structure in Cedrus brevifolia Henry, a narrow endemic Mediterranean tree from Cyprus. Plant Systematics and Evolution, 294: 185-198. https://doi.org/10.1007/s00606-011-0453-z

ELLEGREN H (2004) Microsatellites: simple sequences with complex evolution. Nature Reviews Genetics, 5: 435-445. https://doi.org/10.1038/nrg1348

EXCOFFIER L, LAVAL G, SCHNEIDER S (2005) Arlequin ver. 3.0: An integrated software package for population genetics data analysis. Evolutionary Bioinformatics Online, 1: 47-50. https://doi.org/10.1177/117693430500100003

FALK DA, RICHARDS CM, MONTALVO AM; KNAPP EE (2006) Chapter 2: Population and ecological genetics in restoration ecology. In Foundations of restoration ecology. Edited by D.A. Falk, M.A. Palmer, and J.B. Zedler. Island Press, Washington, D. C. pp. 14-44.

FRANKHAM R, BRISCOE DA, BALLOU JD (2002) Introduction to conservation genetics. Cambridge University Press, New York, New York, USA. https://doi.org/10.1017/cbo9780511808999

GANEA S, RANADE SS, HALL D, ABRAHAMSSON S, GARCIA-GIL MR (2015) Development and transferability of two multiplex nSSR in Scots pine (Pinus sylvestris L.). Journal of Forestry Research, 26(2): 361-368. https://doi.org/10.1007/s11676-015-0042-z

G'OMEZ A, GONZÁLEZ- MARTíNEZ SC, COLLADA C, CLIMENT J, GIL L (2003) Complex population genetic structure in the endemic Canary Islandpine re- 
vealed using chloroplast microsatellite markers. Theoretical and Applied Genetics, 107:1123-1131. https://doi.org/10.1007/s00122-003-1320-2 G'OMEZ- GARAY A, MASSELLI S, BUENO MA (2010) Distribution of Genetic Diversity of Pinus ayacahuite (Ehrenberg) at the Communal Forest of Totonicapan, Guatemala. Bioremediation, Biodiversity and Bioavailability, 4: 35-41.

HAMRICK JL, GODT MJW (1992) Sherman-Broyles, S.L. Factors influencing levels of genetic diversity in woody plant species. New Forest, 6: 95-124.

HANSEN OK, KJÆER ED, Vendramin GG (2005) Chloroplast microsatellite variation in Abies nordmanniana and simulation of causes for low differentiation among populations. Tree Genetics \& Genomes, 1: 116-123. https://doi.org/10.1007/s11295-005-0016-y

HARTL DL, CLARK AG (1997) Principles of Population Genetics, 3rdedn. Sinauer Associates, Inc, Sunderland, MA.

KELCHNER SA (2000) The evolution of non-coding chloroplast DNA and its application in plant systematics. Annals of Missouri Botanical Garden, 87:499527. https://doi.org/10.2307/2666142

LEDIG FT, CAP'O- ARTEAGA MA, HODGSKISS PD, SBAY H, FLORES-L'OPEZ C, CONKLE MT, BERMEJO-VELÁZQUEZ B (2001) Genetic diversity and the mating system of a rare Mexican Piñon, Pinus pinceana, and a comparison with Pinus maximartinezii (Pinaceae). American Journal of Botany, 88(11): 19771987. https://doi.org/10.2307/3558425

L'OPEZ- VINYALLONGA S, L'OPEZ- ALVARADO J, CONSTANTINIDIS TH, SUSANNA A, GARCIA- JACAS N (2011) Microsatellite cross- species amplification in the genus Centaurea (Compositae), Collectanea Botanica, 30: 17-27. https://doi.org/10.3989/collectbot.2011.v30.002

MCDERMOTT JM, MCDONALD BA (1993) Gene flow in plant pathosystems. Annu. Rev. Phytopathol,31: 353-373. https://doi.org/10.1146/annurev.py.31.090193.002033

MILLER CN (1982) Current status of Paleozoic and Mesozoic confers. Review of Palaeobotany and Palynology, 37: 99-114 (Cited by Millar, 1999) https://doi.org/10.1016/0034-6667(82)90039-2

MIROV NT (1967) The genus Pinus. Ronald Press, New York, 602 pp. https://doi.org/10.2307/4004229

MORENO AC, MARCHELLI P, VENDRAMIN GG, GALLO LA (2011) Cross transferability of SSRs to five species of Araucariaceae: useful tool for population genetic studies in Araucaria araucana. Forest Systems, 20(2): 303-314. https://doi.org/10.5424/fs/2011202-11449

MORGANTE M, PFEIFFER A, COSTACURTA A, OLIVIERI AM (1996) Molecular tools for population and ecological genetics in coniferous trees. Phyton-Annales Rei Botanicae, 36: 129- 138.

NEALE DB, SEDEROFF RR (1989) Paternal inheritance of chloroplast DNA and maternal inheritance of mitochondrial DNA in loblolly pine. Theoretical and Applied Genetics, 77: 212-216. https://doi.org/10.1007/bf00266189

NEI M (1987) Molecular Evolutionary Genetics. Columbia University Press, New York. https://doi.org/10.1016/0047-2484(89)90093-6

PERRY JP (1991) The Pines of Mexico and Central America. Timber Press, Portland,OR. https://doi.org/10.2307/1222523

PORTH I, EL-KASSABY YA (2014) Assessment of the genetic diversity in forest tree populations using molecular markers. Diversity, 6: 283-295. https://doi.org/10.3390/d6020283

PROVAN J, SORANZO N, WILSON NJ, MCNICOL JW, FORREST GI, COTRELL J, POWELL E (1998) Genepool variation in Caledonia and European Scots pine (Pinus sylvestris L.) revealed by chloroplast Simple Sequence Repeats. In: Proceedings of Royal Society of London, Series B, 265: 1697-1705. https://doi.org/10.1098/rspb.1998.0491

PROVAN J, SORANZO N, WILSON NJ, GOLDSTEIN DB, POWELL W (1999).A low mutation rate for chloroplast microsatellites. Genetics, 153: 943-947.

QUELLER D, STRASSMANN J, HUGHES CR (1993) Microsatellites and kinship. Trends in Ecology and Evolution, 8:285-288. https://doi.org/10.1016/0169-5347(93)90256-O

RIBEIRO MM, MARIETTE S, VENDRAMIN GG, SZMIDT AE, PLOMION C, KREMER A (2002) Comparison of genetic diversity estimates within and among populations of maritime pine using chloroplast simple-sequence repeat and amplified fragment length polymorphism data. Molecular Ecology, 11: 869-877. https://doi.org/10.1046/j.1365-294x.2002.01490.x

SCHUG MD, SMITH SG, TOZIER-PEARCEA, MCEVEY SF (2007):The genetic structure of Drosophila ananassae populations from Asia, Australia and Samoa. Genetics, 175: 1429-1440. https://doi.org/10.1534/genetics.106.066613
SINCLAIR WT, MONCUR JD, ENNOS RA (1997) Multiple origins for Scots pine (Pinus sylvestris L.) in Scotland: evidence from mitochondria DNA variation. Heredity, 80: 233-240. https://doi.org/10.1038/sj.hdy.6882870

STANGE C, PREHN D, JOHNSON PA (1998) Isolation of Pinus radiata genomic DNA suitable for RAPD analysis. Plant Molecular Biology Reporter, 16: 1-8.

TERRAB A, PAUN O, TALAVERA S, TREMETSBERGER K, ARISTA M, STUESSY TF (2006) Genetic diversity and population structure in naturalpopulations of Moroccan Atlas Cedar (Cedrus atlantica; Pinaceae) determined with cpSSR markers. American Journal of Botany, 93: 1274-1280. https://doi.org/10.3732/ajb.93.9.1274

TORO MA, CABALLERO A (2005) Characterization and conservation of genetic diversity in subdivided populations. Philosophical Transactions of the Royal Society, 360: 1367-1378. https://doi.org/10.1098/rstb.2005.1680

VENDRAMIN GG, LELLILR ROSSI P, MORGANTE M (1996) A set of primers for the amplification of 20 chloroplast microsatellites in Pinaceae. Molecular Ecology, 5: 595-598. https://doi.org/10.1111/j.1365-294x.1996.tb00353.x

VENDRAMIN GG, ANZIDEI M, MADAGHIELE A, BUCCI G (1998) Distribution of genetic diversity in Pinus pinaster Ait. as revealed by chloroplast microsatellites. Theoretical and Applied Genetic, 97: 456- 463. https://doi.org/10.1007/s001220050917

VENDRAMIN GG, ANZIDEI M, MADAGHIELE A, SPERISEN C, BUCCI G (2000) Chloroplast microsatellite analysis reveals the presence of population subdivision in Norway spruce (Picea abies K.). Genome, 43: 68-78. https://doi.org/10.1139/gen-43-1-68

VILLALOBOS- ARÁMBULA AR, PÉRÉZ DE LA ROSA JA, ARIAS A, RAJORA OP (2014) Cross-species transferability of eastern white pine (Pinus strobus) nuclear microsatellite markers to five Mexican white pines. Genetics and Molecular Research,13: 7571-7576. https://doi.org/10.4238/2014.september.12.24

WANG D, SHI J, CARLSON SR, CREGAN PB, WARD RW, Diers BW (2003) Alow cost, high throughput Polyacrylamide gel electrophoresis system forgenotying with microsatellite DNA markers. Crop Science, 43: 1828-1832. https://doi.org/10.2135/cropsci2003.1828

WATANO Y, IMAZU M, SHIMIZU T (1996) Spatial distribution of cpDNA and mtDNA haplotypes in a hybrid zone between Pinus pumila and P. parviflora var. pentaphylla. 2ndedn. Taylor \&Francis Group, CRS Press, New York. https://doi.org/10.1007/bf02344555

WRIGHT S (1951) The genetical structure of populations. Annals of Eugenics, 15: 323-354. https://doi.org/10.1111/j.1469-1809.1949.tb02451.x

XIANG-XIANG F, JI-SEN S (2005) Identification of seeds of Pinus species by Microsatellite Markers. Journal of Forestry Research, 16(4): 281-284. https://doi.org/10.1007/bf02858189

XU Y, ZHANG R, TIAN B, BAI Q, WANG D, CAI N, HE C, KANG X, DUAN A (2013) Development of novel microsatellite markers for Pinus yunnanensis and their cross amplification in congeneric species. Conservation Genetic Resource,5(4):1113-1114. https://doi.org/10.1007/s12686-013-9964-y

YEH FC, YANG RC, BOYLE TBJ (1999) PopGene Version 1.31: Microsoft windows based Freeware for Population Genetic Analysis. University of Albert, Edmonton. http://www.ualbert.ca/fyeh. 